\title{
Relação Médico-Paciente e o Impacto das Palavras nas Emoções, na Saúde e no Bem Estar dos Pacientes
}

\author{
Colares, Francisca Luciana Almeida; Leite, Álvaro Jorge Madeiro; Neves Filho, Almir de \\ Castro; Leite, Vivian Martins dos Santos; Jorge, Iago Farias \\ Universidade Federal do Ceará - luciana_colares@hotmail.com
}

Introdução: Alguns aspectos da comunicação médico-paciente claramente influenciam o comportamento e bem-estar dos pacientes. a fala é o aspecto principal em cuidados médicos e é instrumento fundamental pelo qual a relação médico-paciente é pautada e através da qual objetivos terapêuticos são atingidos. Médicos são bilíngues, utilizam a língua nativa diária e são fluentes na linguagem médica. o uso da linguagem médica em consultas é fonte de problemas para os pacientes enquanto a linguagem diária promove melhor entendimento. Mais que explicar a complexidade de uma situação, médicos podem usar palavras que geram ansiedade, medo ou desesperança. como resultado, pacientes têm dificuldade de tomar decisões inteligentes e de se tornarem agentes do cuidado. Tais emoções também podem agravar sintomas e afetar o processo de cura. o estudo desse aspecto da relação médico-paciente e a conscientização de alunos de medicina para sua importância são necessários para desenvolvimento do atendimento humanizado e satisfatório. Objetivos: Identificar quais as maneiras que médicos utilizam pra se comunicar com pacientes que são mais eficientes e contribuem para o fortalecimento da relação médico-paciente. Destacar possíveis palavras que são memorizadas pelos pacientes por terem sido palavras que suscitaram emoções boas ou ruins. Fazer alunos de medicina atentarem para a importância do uso das palavras corretas para uma relação médico-paciente bem estabelecida. Métodos: Trata-se de uma pesquisa do tipo exploratória-qualitativa que está sendo desenvolvida em um agrupamento hospitalar universitário, abrangendo três grupos de pacientes, internados em enfermaria, recebendo atendimento ambulatorial e mulheres em puerpério imediato. Os dados estão sendo coletados através de entrevista estruturada, gravada, transcrita e analisada. a coleta dá-se após o consentimento livre e esclarecido do paciente. Resultados: Desde o início da pesquisa até o presente momento, foi identificado como aspecto negativo da comunicação verbal o fato dos médicos dizerem o que o paciente tem com 'palavras enfeitadas' sem sequer olha-lo direito, destacando o mal uso da linguagem médica, causando distanciamento e desinformação. como aspecto positivo foi destacada a preocupação com a dimensão sentimental do paciente, como quando um médico falou para a paciente: 'Não se preocupe. a gente tá aqui para ajudar. Se você quiser desabafar, pode contar comigo que a gente conversa'. Conclusões: a comunicação verbal é um aspecto da relação médico-paciente que vem sendo estudada e valorizada por pesquisadores. Concomitantemente, deve ser mais abordada nas faculdades de medicina, tendo em vista o impacto das palavras nas emoções, saúde e bem estar dos pacientes. Conhecer as palavras que são bem acolhidas, e as que não o são, facilita a formação de um profissional mais humano e mais apto para prestar atendimento de boa qualidade.

Colares, Francisca Luciana Almeida; Leite, Álvaro Jorge Madeiro; Neves Filho, Almir de Castro; Leite, Vivian Martins dos Santos; Jorge, lago Farias. Relação Médico-Paciente e o Impacto das Palavras nas Emoções, na Saúde e no Bem Estar dos Pacientes. In: Anais do Congresso Internacional de Humanidades \& Humanização em Saúde [= Blucher Medical Proceedings, num.2, vol.1]. São Paulo: Editora Blucher, 2014. ISSN 2357-7282

DOI 10.5151/medpro-cihhs-10849 